\title{
Review of the History of Animals that Helped Human Life and Safety for Aerospace Medical Research and Space Exploration
}

\author{
Won-Chang Lee, DVM, MPH, Ph.D. ${ }^{1}$, Kyu-Sung Kim, M.D., Ph.D. ${ }^{2}$, Young Hwan Kwon, M.D. ${ }^{3}$ \\ ${ }^{1}$ College of Veterinary Medicine, Konkuk University, Seoul, ${ }^{2}$ Inha Research Institute for Aerospace Medicine and \\ Department of Otorhinolaryngology, Inha University Hospital, Incheon, ${ }^{3}$ Aeromedical Center, Korean Air, Seoul, Korea
}

\author{
Received: December 3, 2019 \\ Revised: December 17, 2019 \\ Accepted: December 27, 2019 \\ Corresponding Author \\ Young Hwan Kwon \\ Aeromedical Center, Korean Air, 260 Haneul- \\ gil, Gangseo-ru, Seoul 07505, Korea \\ Tel: $+82-2-2656-7150$ \\ Fax: +82-2-2656-8848 \\ E-mail: younghkwon@koreanair.com \\ ORCID \\ https://orcid.org/0000-0001-9901-7280
}

\begin{abstract}
In 2019, the Aerospace Medical Association of Korea celebrated its 30th anniversary. On the other side of the world, it was also the 62nd anniversary of Russian launch Sputnik 1 of the world's first artificial satellite on October 4, 1957. In additionally, the world, especially the United States was shocked, when on November 3, 1957, Sputnik 2 blasted into Earth orbit with a dog named "Laika"; it was the role of veterinarian's activities for aerospace medical research and exploration. Veterinarians (Vets) are responsible for the health of all the animals for aerospace medicine whether on the ground or in space. Vets can enhance animal and public health and this knowledge of Vets and astronauts can extend their mission durations, go to nearby Earth Asteroids, Mars and other heavenly bodies to study their living and non-living characteristics. This review article is the brief history of the original growth of the veterinarian's activities for the aerospace medical research, in order to stimulate future strategies for improvements in the space life sciences and exploration.
\end{abstract}

Keywords: Veterinarians, Animals, Aerospace medicine

\section{INTRODUCTION}

In 2019, the Aerospace Medical Association of Korea celebrated its 30th anniversary, its beginning seems like it was only yesterday [1]. On the other side of the world, it was also the 62nd anniversary of Russian launch Sputnik 1 of the world's first artificial satellite on October 4, 1957 [2-5]. In additionally, the world, especially the United States was shocked, when on November 3, 1957, Sputnik 2 blasted into Earth orbit with a dog named "Laika"; it was the role of veterinarian's activities for aerospace medical research and exploration [2-5].

Today's Veterinarieans (Vets) are the doctors educated to protect the health of both animals and people. They work hard to address the health and welfare needs of every species of animals. Vets also play critical roles in environmental protection, biomedical research, food hygiene and safety, public health, and the aerospace and deep-sea medicine in uniformed (military) service [6-9].

Vets are responsible for the health of all the animals for aerospace medicine whether on the ground or in space. When a space shuttle experiment involving animals as the bioastronautics is scheduled, a Vet is consulted to ensure that the animals selected are appropriate for those experiments [8]. They also provide instructions for proper care of the animals during the voyage, including information on how to avoid unacceptable treatments or procedures. At the National Aeronautics Space Administration (NASA) 
Table 1. Review of the brief history of animal researches that helped human life and safety for aerospace medical research and space exploration, the 1950s 2000s

\begin{tabular}{|c|c|c|c|}
\hline Schedule & Carried & Subjects & Experiments \\
\hline Jun/14/1949* & V-2 rocket; 134 km & $\begin{array}{l}\text { Rhesus monkey; } \\
\text { "Albert II". }\end{array}$ & $\begin{array}{l}\text { Monkey; attained an altitude of } 83 \text { miles: died on impact after a } \\
\text { parachute failure. }\end{array}$ \\
\hline Sep/20/1951 & Aerobee; missile & $\begin{array}{l}\text { Monkey; “Yorick” \& } 11 \\
\text { mice }\end{array}$ & $\begin{array}{l}\text { Monkey and } 11 \text { mice; the flight of } 236,000 \mathrm{ft} \text {. } \\
\text { As the first monkey to live through a space flight. }\end{array}$ \\
\hline May/22/1952 & Aerobee; missile & $\begin{array}{l}\text { Two Philippine } \\
\text { Monkey (Patricia \& Mike) } \\
\text { and } 2 \text { mice }\end{array}$ & $\begin{array}{l}\text { Monkeys; rapid acceleration. Fired } 36 \text { miles up at a } 2000 \text { mph to } \\
\text { reach a high altitude. Also on this flight were two mice. }\end{array}$ \\
\hline $1951 \sim 1952$ & SOVIET; R-1 Rocket & Nine dogs & $\begin{array}{l}\text { Carried nine dogs altogether, with three dogs flying twice that } \\
\text { recovered by parachute. }\end{array}$ \\
\hline 1950 1954 & $\begin{array}{l}\text { Balloon flight; } 27 \sim 30 \mathrm{~km} / \\
\text { Alti. Up to } 28 \text { hrs. }\end{array}$ & $\begin{array}{l}\text { Monkeys, hamsters, } \\
\text { dogs, cats, mice \& } \\
\text { Fruit flies }\end{array}$ & The effects of the thin atmosphere and radiation. \\
\hline 1951 1954 & Aerobee 71 km/altitude & Rh-monkey, mice & $\begin{array}{l}\text { Rh-monkeys and mice were flown to study the effects of cosmic } \\
\text { radiation and changes in the cardiovascular system. }\end{array}$ \\
\hline $1951 \sim 1952$ & Aerobee; 71 km/Alti. & Rh-monkeys, mice & $\begin{array}{l}\text { The effects of cosmic radiation and changed in the cardiovascular } \\
\text { system. }\end{array}$ \\
\hline Nov/3/1957* & SOVIET; Sputinik-2 & Dog; “Laika” & $\begin{array}{l}\text { A dog named "Laika" blasted into Earth orbit. She was hastily } \\
\text { trained and put aboard in metal carriers under the second Sputnik } \\
\text { sphere. Sputnik finally burned up in the outer atmosphere in April } \\
1968 .\end{array}$ \\
\hline Dec/4/1959 & $\begin{array}{l}\text { Joe rocket. Speed: } \\
3,685 \mathrm{mph} / \mathrm{min} \text {. }\end{array}$ & Rh-monkey "Sam" & $\begin{array}{l}\text { Test for alive in highly seed fight; } 1 \text { minute into the flight, a speed } \\
\text { of 3,685 mph. After attending an altitude of } 51 \text { miles, with no ill } \\
\text { effects from his journey. }\end{array}$ \\
\hline Jan/21/1960 & $\begin{array}{l}\text { Joe rocket. Flight to } \\
84 \mathrm{~km} \text { altitude }\end{array}$ & Rh-monkeys & $\begin{array}{l}\text { Rh-monkey Sam and Miss Sam on the second flight; verification of } \\
\text { Mercury life support equipment. }\end{array}$ \\
\hline \multicolumn{4}{|c|}{ ATLAS (USA): Survival tests in space } \\
\hline 1960 & $\begin{array}{l}\text { Atlas rocket; } 650 \\
\text { km/Alti. }\end{array}$ & Mice & Three mice flight in space; effects of alive. \\
\hline \multicolumn{4}{|c|}{ VOSTOK (Soviet): The first human to journey into space } \\
\hline Apr/12/1961 & Vostok-1 & Man: Yuri A Gagarin. & $\begin{array}{l}\text { The first human to journey into space. His capsule completed on- } \\
\text { orbit of Erath. }\end{array}$ \\
\hline
\end{tabular}


Table 1. Continued 1

\begin{tabular}{|c|c|c|c|}
\hline Schedule & Carried & Subjects & Experiments \\
\hline \multicolumn{4}{|c|}{ MERCURY (USA); Initiated to demonstrate that human can survive in space } \\
\hline Jan/31/1961 & Mercury-2 & Chimpanzee (Ham) & $\begin{array}{l}\text { A suborbital flight, Chimpanzee Ham was closely monitored for the } \\
\text { cardiovascular responses. It is the first initial suborbital flight in } \\
\text { space. }\end{array}$ \\
\hline May/5/1961 & $\begin{array}{l}\text { Mercury-3; Rocket } \\
259 \text { km/Alti.15 minutes }\end{array}$ & Man: Alan B. Shepard & $\begin{array}{l}\text { The First suborbital flight of man; monitoring the physiological } \\
\text { responses of astronaut American. }\end{array}$ \\
\hline Feb/20/1962 & $\begin{array}{l}\text { Mercury-6; (Atlas } \\
\text { rocket). } 4 \text { hrs } 55 \text { min. }\end{array}$ & Man: John Glenn & $\begin{array}{l}\text { First orbital flight of American astronaut. The physiological } \\
\text { responses of the astronaut were monitored. }\end{array}$ \\
\hline \multicolumn{4}{|c|}{ FRANCE: The first cat and pig-tailed macaque into space exploration } \\
\hline Oct/18/1963* & AGI rocket-47; & Cat. "Félix" & $\begin{array}{l}\text { Cat, named Félix the first cat into space. } \\
\text { Recovered alive after a } 15 \mathrm{~min} \text { for } 130 \text { miles flight. }\end{array}$ \\
\hline \multicolumn{4}{|c|}{ SOVIET; Experiment research for radiation effects in space exploration } \\
\hline Feb/22/1966 & SOVIET; Cosmos-110. & $\begin{array}{l}\text { Two dogs. "Veterok" } \\
\text { and "Ugoyok" }\end{array}$ & $\begin{array}{l}\text { Two dogs; named "Veterok" and "Ugoyok" were radiation effects: } \\
21 \text {-day in space still stands as a canine record. }\end{array}$ \\
\hline \multicolumn{4}{|c|}{ GEMINI: Growth experiments of Frog eggs in space, and tortoises to the Moon. } \\
\hline Mar/16/1966 & Genini-8; 10 hrs 41 min. & Frog eggs & First docking in space, Frog egg growth-experiment. \\
\hline Nov/11 15/1966 & $\begin{array}{l}\text { Gemini-12; 3EVA's. One } \\
\text { lasting } 5 \text { hrs. }\end{array}$ & Frog eggs & Frog egg growth-experiment. \\
\hline Sep/14/1968* & $\begin{array}{l}\text { SOVIET; Zond-5, } \\
\text { Circumlunar voyage }\end{array}$ & Two tortoises & $\begin{array}{l}\text { The first animals in deep space, the first to circle the Moon, and } \\
\text { the first Horsfield's tortoises. The first inhabitants of Earth to } \\
\text { travel around the Moon. }\end{array}$ \\
\hline July/20 24/1969 & $\begin{array}{l}\text { A Saturn V- Rocket; } \\
\text { Apollo-11: Columbia }\end{array}$ & $\begin{array}{l}\text { Man: Neil Amstrong, } \\
\text { Buzz Aldrin, and } \\
\text { Michael Collins }\end{array}$ & $\begin{array}{l}\text { Apollo } 11 \text { was the spaceflight that first landed human on the moon. } \\
\text { Armstrong's first step on to the lunar surface was a worldwide } \\
\text { audience on July 20,1969 at 20:17 UTC. }\end{array}$ \\
\hline \multicolumn{4}{|c|}{ APOLLO; Biomedical experiments requiring no or only small additional hardware items were flown } \\
\hline Dec/7 19/1972 & $\begin{array}{l}\text { Apollo-17; Sixth and last } \\
\text { lunar landing }\end{array}$ & Five-pocket mice & $\begin{array}{l}\text { BIOCORE, five pocket mice were flown to study HZE radiation } \\
\text { effects. }\end{array}$ \\
\hline \multicolumn{4}{|c|}{ APOLLO-SOYUZ (ASTP); The first rendezvous and docking of American and Russian spacecraft } \\
\hline Nov/9 15/1970 & Orbiting; Otolith-A. & Two Bullfrogs & $\begin{array}{l}\text { Upon entering microgravity several changes in vestibular } \\
\text { responses of the bullfrog were noted. All observed changes were } \\
\text { back to normal during the last } 10-20 \text { hours of the space flight. }\end{array}$ \\
\hline
\end{tabular}


Table 1. Continued 2

\begin{tabular}{|c|c|c|c|}
\hline Schedule & Carried & Subjects & Experiments \\
\hline \multicolumn{4}{|c|}{ COSMOS-SOVIET; A biosatellite was a missions to biological Ex. in unmanned, launched in 1966} \\
\hline Nov/25 15/1975 & Cosmos-782; 20 days & $\begin{array}{l}\text { Rats, fruit flies and } \\
\text { killifish eggs }\end{array}$ & $\begin{array}{l}\text { Immunology \& musculoskeletal adaptation as well as radiation } \\
\text { effects on animals. }\end{array}$ \\
\hline Aug/3 22/1977 & Cosmos-936; 19 days & Rats and fruit flies & $\begin{array}{l}\text { Effects on biological stems and outcomes radiation. Usage of } \\
\text { centrifuge as a countermeasure to microgravity. }\end{array}$ \\
\hline Sep/25 Oct/14/1979 & Cosmos-1129 19 days & Rats and Japanese quail & Radiation; mammalian reproduction and embryogenesis in space. \\
\hline Dec/14 19/1983 & Cosmos-1514 Five days & Rh-monkeys \& rats & $\begin{array}{l}\text { Circadian rhythms in Rh-monkeys and morphological development } \\
\text { of rat fetus. }\end{array}$ \\
\hline Jul/10 17 1985 & $\begin{array}{l}\text { Cosmos-1667 Seven } \\
\text { days }\end{array}$ & Rh-monkeys & $\begin{array}{l}\text { Cardiovascular and cardiopulmonary } \\
\text { Adaptation processes in Rh-monkeys }\end{array}$ \\
\hline Sep/29 Oct/12/1987 & Cosmos-1887 13 days & Rh-monkeys & $\begin{array}{l}\text { Effects on the biological system in rats and quantitative analysis of } \\
\text { skeletal changes in primates. }\end{array}$ \\
\hline Sep/15 29/1989 & Cosmos-2044 14 days & Rh-monkeys \& rats & $\begin{array}{l}\text { Effects of spaceflight on circadian rhythms, temperature regulation } \\
\text { and metabolism as well as neuromuscular adaptation in Rh- } \\
\text { monkeys. And to repeat the rat analyses on Cosmos-1887. }\end{array}$ \\
\hline Dec/29/1992 Jan/10/1993 & Cosmos-2229 13 days & Rh-monkeys & Bone, neuromuscular and vestibular \\
\hline & & & $\begin{array}{l}\text { Physiology circadian rhythms/meta-holism, two Rh-monkeys } \\
\text { served as experimental subjects. }\end{array}$ \\
\hline \multicolumn{4}{|c|}{ SPCE-SHUTTLE; The world's first reusable spacecraft \& the US vehicle having a standard sea-level atmospheric pressure composition } \\
\hline Aug/30 Sep/5/1983 & $\begin{array}{l}\text { STS-8; Challenger, } \\
\text { TDRS-deploy }\end{array}$ & Rodents & $\begin{array}{l}\text { Extensive monitoring of fluid shifts vesicular/neurosensory } \\
\text { changes, rodent studies. }\end{array}$ \\
\hline Apr/6 13/1984 & $\begin{array}{l}\text { 41-C; First Satellite } \\
\text { repair. }\end{array}$ & Rodents & Gravitational biology studies using rodents. \\
\hline Apr/29 May/6/1985 & 51-B; Spacelab-3 & $\begin{array}{l}\text { Rodents and small } \\
\text { primates }\end{array}$ & $\begin{array}{l}\text { Tests of Research Animal Holding Facility for rodents and small } \\
\text { primates, visual observations confirmed motion sickness } \\
\text { in primates, experiments in exercise and fluid-loading as } \\
\text { countermeasures for cardiovascular reconditioning. }\end{array}$ \\
\hline Mar/13 18/1989 & STS-29; TDRS-D & Rodents \& chicken & $\begin{array}{l}\text { Chromosome and plant cell division experiment, protein crystal } \\
\text { growth and rodent bone- } \\
\text { Healing experiment, chicken embryo development. }\end{array}$ \\
\hline Oct/6 10/1990 & STS-41; Ulysses & Rodents & $\begin{array}{l}\text { Orthostatic function tests during entry, landing and egress, postural } \\
\text { equilibrium control tests during landing and egress, visual- } \\
\text { vestibular integration studies, gravitational-biology studies. }\end{array}$ \\
\hline Jun/5 14/1991 & STS-40; SLS-1. & Human \& rodents & $\begin{array}{l}\text { First space mission dedicated to biological research, exams. In } \\
\text { cardiovascular, cardio-pulmonary, neurovestibular, muscle and } \\
\text { bone physiology in both human and rodent subjects. }\end{array}$ \\
\hline Sep/12 18/1991 & STS-48 & Rodents & $\begin{array}{l}\text { Gravitational-biology studies with rodents, radiation monitoring and } \\
\text { studies of cosmic radiation effects. }\end{array}$ \\
\hline Sep/12 20/1992 & STS-47; Spacelab-J & Animals \& human & $\begin{array}{l}\text { Ex. Investigating human and health, cell separation, developmental } \\
\text { biology for animal and human physiology and behavior, radiation } \\
\text { and biological rhythms. }\end{array}$ \\
\hline Jan/13 19/1993 & STS-54; TDRS-F & Rodents & $\begin{array}{l}\text { Gravitational biology studies, evaluation of cardiovascular and } \\
\text { musculoskeletal deconditioning on rodents. }\end{array}$ \\
\hline Apr/8 17/1993 & $\begin{array}{l}\text { STS-56; ATAS-2 } \\
\text { Spartan } 201\end{array}$ & Rodents & $\begin{array}{l}\text { Physiological and anatomical studies on rodents, tissue loss and } \\
\text { radiation effects. }\end{array}$ \\
\hline Jan/8 23/1994 & STS-65; IML-2 & Aquatic animals & $\begin{array}{l}\text { Gravisenory test of aquatic animals, rotating centrifuge (Hypogravity } \\
\text { Exams), spinal changes in humans and LBNP. }\end{array}$ \\
\hline Sep/30 Oct/11/1994 & STS-64; SRL-2 & Insects (spiders) & $\begin{array}{l}\text { Radiation monitoring, physiological- } \\
\text { Processes in insects such as spiders, } \\
\text { centipedes and crustaceans. }\end{array}$ \\
\hline
\end{tabular}


Table 1. Continued 3

\begin{tabular}{|c|c|c|c|}
\hline Schedule & Carried & Subjects & Experiments \\
\hline Jul/13 21/1995 & STS-70; TDRS-G & $\begin{array}{l}\text { Rats, Medaka } \\
\text { embryos \& plant }\end{array}$ & $\begin{array}{l}\text { Radiation monitoring, effects of micro-gravity on embryogenesis of } \\
\text { rats and Medaka embryos, plant growth and development. }\end{array}$ \\
\hline May/19 29/1996 & $\begin{array}{l}\text { STS-77; Spacelab-4 } \\
\text { Spartan }\end{array}$ & Rats and plants & $\begin{array}{l}\text { Immune system of the rat, production of pharmaceutical revenant } \\
\text { substances in plants and effects of space flight on anthropoid and } \\
\text { plant spaces. }\end{array}$ \\
\hline Jun/20 Jul/7/1996 & $\begin{array}{l}\text { STS-78; Life \& } \\
\text { microgravity Spacelab: } \\
\text { Life \& Microgravity. } \\
\text { Space Shuttle }\end{array}$ & Human, rats, and plants & $\begin{array}{l}\text { Musculoskeletal experiments, research in metabolic, pulmonary and } \\
\text { neuroscientific areas, investigations concerning human behavior } \\
\text { and performance in space. Also biology Ex. In investigating bone } \\
\text { loss in rats and lignin formation in plants. }\end{array}$ \\
\hline During the 1990s 2000s & $\begin{array}{l}\text { STS-90; Neurolab. } \\
\text { Space Shuttle }\end{array}$ & $\begin{array}{l}\text { Rats, mice, crickets, snail, } \\
\text { two kind's fish and men: } \\
\text { the crew members } \\
\text { themselves }\end{array}$ & $\begin{array}{l}\text { Neurolab was a Spacelab module mission for the effects of } \\
\text { microgravity on the nervous system. In the here, one of the } \\
\text { astronauts, Dr. R.M. Linnehan, DVM has two spaceflights, and } \\
\text { has veterinary mission specialist for aerospace medical research } \\
\text { logged more than } 58 \text { days in space shuttle }[4,7,8,15] \text {. }\end{array}$ \\
\hline
\end{tabular}

Remarks: the raw data were collected and modified from the references [3-4,8-15].

*The first bioastronauts activities of each animal into space exploration.

headquarters, the duties of Vets include monitoring the health of research animals, planning and conducting experiments, collecting data/measurements, interpreting the results of their research, and writing reports on their finding for NASA [3,4,8-11].

Vets can enhance animal and public health and this knowledge of Vets and astronauts can extend their mission durations, go to nearby Earth Asteroids, Mars and other heavenly bodies to study their living and non-living characteristics $[2,3,6,9]$.

In this present review, we go over the brief history of the original growth of the veterinarian's activities for the aerospace medical research, in order to stimulate future strategies for improvements in the space life sciences and exploration.

\section{BODY}

\section{Animals that helped human life and safety in space exploration}

In the earlier days of space exploration, nobody knew if people could survive a trip away from Earth, so using animals was the best way to find out $[3,4,8,9]$. Nonetheless, before humans actually went into space, one of the prevailing theories of the perils of space flight was that humans might not be able to survive under long periods of weightlessness. Over the last century, American and Rus- sian scientists utilized animals - mainly monkeys, chimps and dogs - in order to test each country's ability to launch a living organism into space and bring it back alive and unharmed [3-6,9-11].

However, despite losses, these animals have taught the scientists a tremendous amount more than could have been learned without them. A wide variety of non-human animals have been launched into space, including monkeys, dogs, cats, mice, tortoises, and insects. The United States launched flights containing monkeys and primates primarily between 1948 1961 with one flight in 1969 and one in 1985. France launched one cat carrying flight in 1963. The Soviet Union and Russia launched monkeys between 1983 and 1996 [3,11-13]. During the 1950s and 1960 s, the Soviet space program used a number of dogs for suborbital and orbital flight [13]. Two tortoises and a variety of insets were the first inhabitants of Earth to circle the Moon, on the 1968 Zond-5 mission, and five mice traveled in the orbiter of the 1972 Apollo 17 Moon mission [13]. On the other hand, STS-78 was the fifth dedicated Life and Microgravity Spacelab mission for the Space Shuttle program, flown partly in preparation for the International Space Station (ISS) project. The mission used the Space Shuttle Columbia launch pad 39-B on June 20, 1996, and the mission duration was 16 days, 21 hours in the space [14]. Moreover, STS-90 Neurolab was a 1998 Space Shuttle mission flown by the Space Shuttle 
Columbia. The 16-day mission marked the last flight of the European Space Agency's Space-laboratory module [15]. Table 1 reviews the brief history of animals' help on human life and safety for the aerospace medical research and space exploration, the 1950s 2000s.

\section{Bioastronautics' mission of vertebrates' for aerospace medical research into the space life and exploration}

The bioastronauts of animal astronauts' in space served to test the survivability of spaceflight before human spaceflight was attempted. Later, other non-human animals were flown to investigate various biomedical processes and the effects that microgravity and spaceflight might have on them [3-8,11]. Since the very beginning of space exploration, vertebrate animals have been used in space exploration programs. Albert II, a Rhesus monkey, became the first monkey in space on 14 June 1949, in a U.S.-launched V-2, after the failure of the original Albert' s mission on ascent. Albert II reached about 83 miles [11], as shown in Table 1. On the other hand, on 22 July 1951, the Soviet Union launched the R-1 IIIA-1 flight carrying the dogs (Tsygan and Dezik) in space, but not orbit [11,12]. On 3 November 1959, the second-ever orbiting spacecraft took the first animal into orbit, the dog "Laika" [11,13]. On 18 October 1963, France Launched Felicette the cat named Félix aboard Véronique AGI sounding rocket No. 47. The launch was directed by the French Center d' Enseignement et Recherches de Medicine Aeronautique (CERMA). Felicette was recovered alive after 15 minutes of a 130 miles flight and a descent by parachute; she was monitored with electrodes implanted into her brain and recorded neural impulses were transmitted back to Earth $[11,14]$. The first animals in deep space, the first to circle the Moon, and the first two tortoises in space were launched on Zond-5 on 14 September 1968 by the Soviet Union. The Horsfield's tortoises were sent on a circumlunar voyage to the Moon along with flies, mealworms, and other biological specimens. These were the first inhabitants of Earth to travel around the Moon. The capsule overshot its terrestrial landing site but was successfully recovered at sea on 21 September. The animals survived but suffered from weight loss [11]. Nevertheless, in September 2007, during the European Space Agency's FOTON-M3 mission, tardigrades, also known as water-bears, were able to survive ten days of exposure to open-space with only their natural protection $[9,11]$. It was a landmark for vertebrates' bioastronauts in space life sciences research and exploration.

\section{CONCLUSION AND RECOMMEND}

Veterinarians' activities in aerospace medical research and astronauts can extend their mission durations, go to nearby Earth Asteroids, Moon, Mars and other heavenly bodies to study their living and non-living characteristics [2-4,8-15]. There is a strong relationship between the field of aerospace medicine and veterinary medicine including biomedical activities which can improve the techniques in the laboratory for space life research.

On the other hand, October 10, 2019, the Korea Aerospace Research Institute (KARI) celebrated its 20th anniversary [16]. It is our pleasure to personally recommending that the KARI has the potential for collaboration with the Aerospace Medical Association of Korea (ASMAK) in many areas including aerospace medicine and space life science, and human space flight and exploration. There is a bright future should the National Aeronautics and Space Administration of Korea (NASAK) be established for the National Projects of the Space life research and Exploration.

\section{ACKNOWLEDGEMENTS}

Thanks for the raw data of the references [3-15].

\section{CONFLICTS OF INTEREST}

No potential conflict of interest relevant to this article was reported.

\section{ORCID}

Won-Chang Lee, https://orcid.org/0000-0001-7163-5183

Kyu-Sung Kim, https://orcid.org/0000-0002-5650-3526

Young Hwan Kwon, https://orcid.org/0000-0001-9901-7280

\section{REFERENCES}

1. Lee WC. A Brief History of Original Growth for Aerospace Medicine in Korea. 1952-1970. (Korean). The KJAsEM, 2019;29;1:14-18. 
2. Lee WC. Veterinary Medicine for Aerospace Medicine. The KJAsEM, 2010;20:1:1-6.

3. National Aeronautics and Space Administration (NASA). A brief history of animal in space. NASA History Division.Online at http://history.nasa.gov/animals.html.

4. American Veterinary Medical Association (AVMA). Veterinarian Help Animals in Space. A teacher resource developed by the AVMA. Online at http://www.avma.org/educators/teacher_guidespace_bgnd.pdf/.

5. Hodkinson PD, Anderton RA, Poseselt BN, Fong KJ. An overview of space medicine. British $J$ of An aesthesia (BJA). 2017;119(s1):i143-i153.

6. American Veterinary Medical Associations (AVMA). Veterinarians: Protecting the Health of Animals and People. News and Publication, 2019.10.29. AVMA. Online at http://www. avma.org/public/YourVet/Pages/Veterinarians.aspx/.

7. Richard M. Linnehan. Biographical Data, National Aeronautics and Space Administration (NASA). January 2016. Online at https://www.nasa.gov/sites/default/files/atoms/ files/linnehan_richard.pdf.

8. Cima Greg. (Linnehan RM). Applying veterinary training space travel. JAVMA News. AVMA: Our Passion. Our profession. Oct. 15, 2016. Online at http://www.avma.org/News/ JAVMANews/Pages/161015b.aspx?PF=1.

9. Boro P, Naha, BC, Madkar AR, et al. Role of Veterinarians in Space Research \& Exploration. Intl. J. Vet Sci \& Animal Husbandry. 2016;1(1):16-18.

10. Havelka Jacque and Heath Julie. History of Space Life Sciences. NASA Official: Katherin Newkirk, Last Update: August 31, 1997. Online at http://neurolab.jsc.nasa.gov./ ustime.htm.

11. Wikipedia. Animals in space. Retrieved in Nov, 11, 2019. Online at https://enwikpedia.org/wiki/Animals_in_space/.

12. Siddiqi AA. Challenge to Apollo: The Soviet Union and the Space Race, 1945-1974). Online at https://history.nasa.gov/ SP-4408pt1.pdf.

13. Berger E. "The first creature in space was a dog. She died miserably 60 years ago”. 3 Nov 2017. Ars Technica. Retrieved 3 Nov. 2017.

14. National Aeronautics and Space Administration (NASA). Space Shuttle Mission STS-78, June 1996. Online at https:// www.nasa.gov/mission_pages/shuttle/shuttlemissions/archives/sts-78.htm.

15. National Aeronautics and Space Administration (NASA). Space Shuttle Mission STS-90, April, 1998. Online at https:// www.nasa.gov/mission_pages/shuttle/shuttlemissions/archives/sts-90.html.

16. Korea Aerospace Research Institute (KARI). The 20th Anniversary of KARI, October 10, 2019. KARI. On line at https:// www.kari.re.kr. 